\title{
DESCRIÇÕES E NOTAS SOBRE CERAMBYCIDAE (COLEOPTERA) SUL-AMERICANOS
}

\author{
Ubirajara R. Martins ${ }^{1}$ \\ Maria Helena M. Galileo ${ }^{2}$
}

\begin{abstract}
Descriptions and notes on Cerambycidae (Coleoptera) from SOUTH AMERICA. New taxa described: Cerambycinae, Achrysonini-Ectenessa andrei, sp.n. (Brazil: Rio Grande do Sul); Lamiinae, Lamiini - Neoptychodes cosmeticus, sp.n. (Equador); Onciderini-Charoides pepoata, sp.n. (Bolívia); Venustus analogus, sp.n. (Colombia); Oncideres mirim, sp.n. (Brazil: Pará); Compsosomatini Compsosoma monnei, sp.n. (Bolivia); Desmiphorini - Desmiphora auatinga, sp.n. (Ecuador); Iurubanga, gen.n., I. arixi, sp.n. (Brazil: Paraná, Santa Catarina); Acanthoderini-Acakyra, gen.n., A iaguara, sp.n. (Colombia); Anisocerini-Phacellocera susua, sp.n. (Equador); Falsamblesthiini - Camixaima, gen.n., C. beraba, sp.n. (Equador); Calliini - Callisema iucaua, sp.n. (Peru); Lustrocomus, gen.n., L. paraensis, sp.n. (Brazil: Pará). Fredlanella, nom.n. is given to Taperinha Lane, 1964 non Linnavuori, 1959 (Homoptera). Neomoema, nom. n. is proposed for Moema Martins \& Galileo, 1992 non Costa, 1989 (Pisces). Anisocerus palliatus White, 1855 is transferred to the genus Phacellocera Laporte, 1840. Notes are presented on Calocomus kreuchelyi Buquet, 1840 (Prioninae, Calocomini) and Venustus zeteki Dillon \& Dillon, 1945 (Lamiinae, Onciderini). A key to the species of Callisema Martins \& Galileo, 1990 (Lamiinae, Calliini) is added.

KEY WORDS. Cerambycidae; Coleoptera; Neotropical; South America; taxonomy.
\end{abstract}

Nos últimos anos tem-se recebido vultoso material para identificação procedente de diferentes áreas geográficas e pertencente a diversas Instituições; seu estudo tem resultado na descoberta de novos táxons que devem ser descritos para que se processe a devolução do material-tipo. Este trabalho é uma reunião de descrições, de observações sobre espécies conhecidas e de resolução de problemas nomenclaturais.

As abreviaturas mencionadas no texto correspondem às seguintes Instituições: CMNC, Canadian Museum of Nature, Ottawa; CNCI, Canadian National Collections of Insects, Biosystematics Research Institute, Ottawa; MHNB, Museo de Historia Natural, Bogotá; MNHN, Museu National d'Histoire Naturelle, Paris; MNHU, Museum für Naturkunde, Humboldt Universität, Berlim; MNRJ, Museu Nacional, Rio de Janeiro; MCNZ, Museu de Ciências Naturais, Fundação Zoobotânica, Porto Alegre; MZSP, Museu de Zoologia, São Paulo; UNCM, Museo de Entomologia "Francisco Luis Gallego", Departamento de Biologia, Facultad de Ciencias, Medellín.

Todas as dimensões ao longo das descrições são dadas em milímetros.

1) Museu de Zoologia, Universidade de São Paulo. Caixa Postal $7172,01064-970$ São Paulo, São Paulo, Brasil. Pesquisador do CNPq.

2) Museu de Ciências Naturais, Fundação Zoobotânica do Rio Grande do Sul. Caixa Postal 1188, 90001-970 Porto Alegre, Rio Grande do Sul, Brasil. Pesquisadora do CNPq. 


\section{Prioninae}

\section{Calocomini}

\section{Calocomus kreuchelyi Buquet, 1840}

Calocomus kreuckelyi Buquet, 1840a:142.

Calocomus kreuchelyi; Buquet, 1840b: 1, est. 50; Galileo \& Martins, 1994: 501, fig. 42.

Calocomus lycius Buquet, 1840a: 142.

Material examinado. ColôMBIA, Meta: Puerto Gaitan (bosque galeria, sobre tronco), fêmea, 1.VIII.1985, F. Fernandez leg. (MHNB, $n^{\circ}$ 4443).

O exame deste exemplar nos permite ampliar a distribuição geográfica desta espécie, conhecida apenas pelos holótipos de C. kreuchelyi e de C. lycius procedentes, respectivamente, de Santa Fé de Bogotá e da Colômbia.

Nesta fêmea, as antenas têm 20 artículos; extremidades dos flabelos dos artículos VII-X alaranjadas e artículos XI-XX inteiramente alaranjados. Élitros alaranjados, exceto na região umeral e nos frisos sutural e marginal, castanhos. Nos tipos, segundo as descrições, os élitros são uniformemente acastanhados.

Gula fina e densamente áspera. Prosterno, mesosterno (exceto tubérculo mesosternal), mesepisternos, mesepimeros, metepisternos e lados do metasterno com pilosidade branca relativamente densa.

\section{Cerambycinae}

\section{Achrysonini}

\section{Ectenessa andrei, sp.n.}

Fig. 5

O epíteto é um preito de amizade a André Franco Franceschini, coletor do holótipo e bolsista do MCNZ.

Macho. Tegumento vermelho-alaranjado; bases dos fêmures, tíbias, tarsos com tegumento amarelado. Cada élitro com duas manchas dorsais amarelas com perímetro preto: a anterior, elíptica, muito alongada, ocupa grande parte da metade anterior, com costa saliente; a posterior arredondada, situada atrás do meio e distante da declividade apical, com costa indicada. Cabeça com pontos grandes, rasos e densos. Lobos oculares superiores distantes com quatro fileiras de omatídios. Antenas atingem o ápice elitral aproximadamente na ponta do antenômero VII. Escapo microesculturado com pontos rasos, densos e ásperos. Carenas dos flagelômeros basais pouco salientes. Protórax mais longo que largo, mais constrito na base do que na região anterior, com lados arredondados. Pronoto sem manchas escuras; metade anterior com pontuação grosseira, a posterior com pontos menores, individualizados, rasos, exceto numa área centro-basal microesculturada; calosidades pouco projetadas, microesculturadas no topo. Lados do protórax grosseira e densamente pontuados. Essa pontuação, sexual, invade os lados do prosterno; meio do 
prosterno liso. Mesosterno liso. Processo mesosternal esparsamente pontuado. Élitros densamente pontuados até o terço apical onde a pontução é mais esparsa; cada élitro com pelo menos seis filieiras de pontos pilíferos pouco alinhados. Extremidades levemente oblíquas ou arredondadas, sem projeção no ângulo externo. Fêmures anteriores com quilha dorsal. Meso- e metatíbias finamente carenadas.

Fêmea. Antenas atingem o ápice elitral aproximadamente na extremidade do antenômero VIII. Protórax com pontuação rasa, densa e uniforme, exceto sobre calosidades e área centro-basal do pronoto. Prosterno sem pontos, finamente rugoso em sentido transversal.

Dimensões, respectivamente macho/fềmea. Comprimento total 11,4-11,3/ 12,7. Protórax: comprimento 2,2-2,2/2,2; maior largura 2,0-1,8/1,9. Comprimento elitral 8,1-8,2/9,4; largura umeral 2,2.

Holótipo macho. BrasiL, Rio Grande do Sul: Cambará do Sul, 19-21.XII. 1994, A. Franceschini leg. (MCNZ). Parátipos: fêmea, mesmos dados do holótipo (MCNZ); macho, mesma procedência, 21.XII.1994, E.H. Buckup leg. (MZSP); fềmea, São Francisco de Paula, 16.X.1939, P. Buck leg. (MNRJ).

Discussão. No holótipo os lados do protórax são menos acentuadamente abaulados e o aspecto geral é mais alongado.

Na chave para espécies de Ectenessa (NAPP \& MARTINS 1982), E. andrei insere-se no dilema 9 com E. ocellata (Gounelle) e E. fenestrata (Gounelle). Separa-se de ambas: aspecto corporal mais esbelto e alongado; calosidades e área centro-basal do pronoto microesculturadas; carenas dos flagelômeros basais indistintas; extremidades femurais concolores.

\section{Lamiinae}

\section{Lamiini}

\section{Neoptychodes cosmeticus, sp.n.}

Fig. 1

Fêmea. Tegumento vermelho-acastanhado, revestido por pubescência branco-acinzentada mais densa na face ventral do corpo. Pubescência branca, densa, reveste: faixa que se inicia na metade inferior da fronte e recobre as genas junto aos lobos oculares inferiores; faixa larga nos lados da cabeça; faixa estreita que se inicia entre os lobos oculares superiores e vai até o occipício, dividida pela sutura coronal; faixa larga nos lados do protórax; faixa longitudinal estreita no meio do pronoto; escutelo; faixa larga nos lados dos élitros que se inicia no lado inferior dos úmeros e alcança os ápices; três ou quatro máculas na metade anterior de cada élitro, e três, pouco maiores, junto do friso sutural; pequena área nos lados posteriores do metasterno e pequena mácula nos lados dos urosternitos. As antenas atingem as extremidades elitrais aproximadamente no ápice do antenômero VII. Lado inferior dos antenômeros III e IV com franja densa de pêlos curtos. Sexto basal dos élitros com grânulos abundantes, os mais basais fundidos entre si, constituem elevações 
transversais. Extremidades dos élitros com espinho no ângulo interno. Mesosterno com tubérculo pouco projetado.

Dimensões holótipo fêmea. Comprimento total 25,2. Protórax: comprimento 4,1; maior largura 5,0. Comprimento elitral 18,2; largura umeral 7,0.

Holótipo fêmea. ColômBiA, Valle del Cauca: Cali, VIII.1969, L. Denhez leg. (MNRJ). Parátipos: macho, mesmos dados do holótipo, 1970 (MZSP). Fêmea, EQUADOR, Pichincha: Santo Domingo (Tinalandia 16km S, 680m), 15-28.VI.1975, S. \& J. Peck leg. (CMNC).
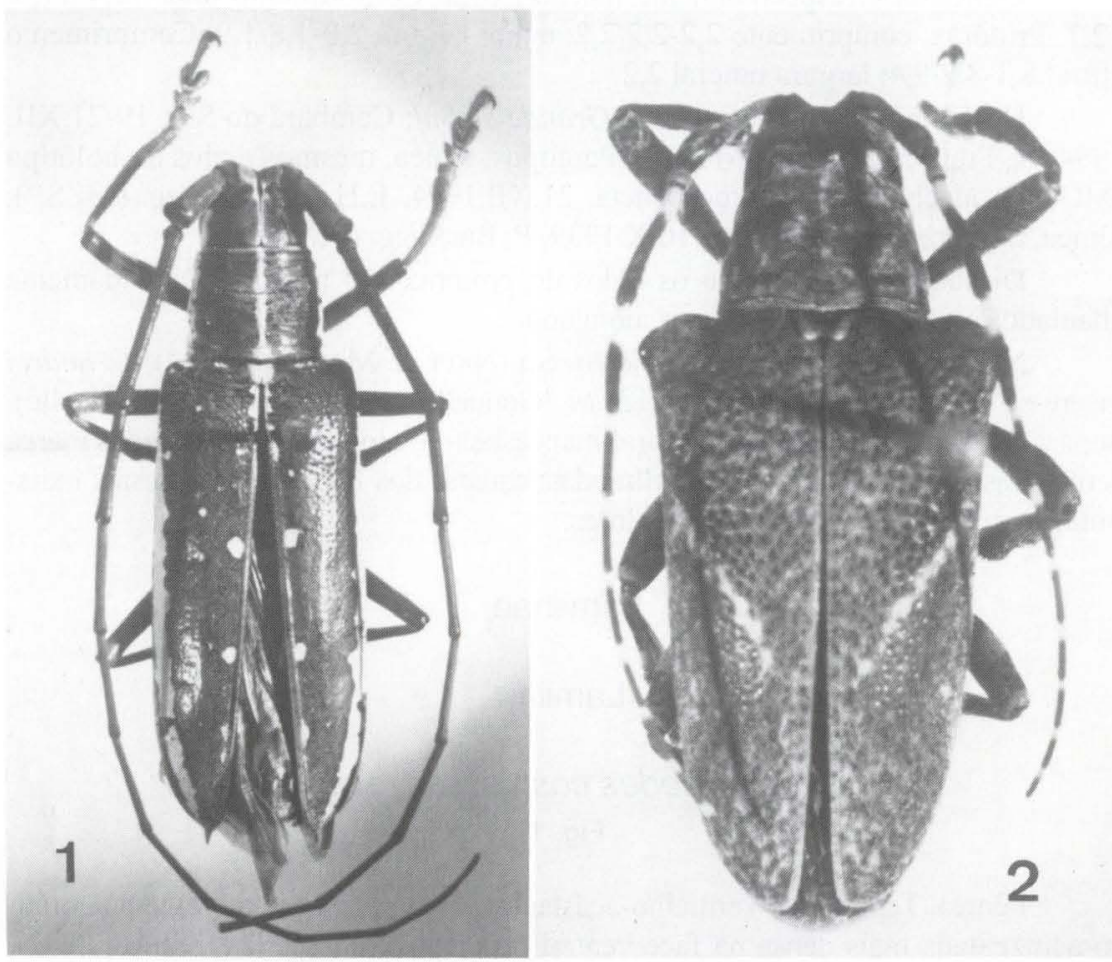

Figs 1-2. (1) Neoptychodes cosmeticus, sp.n., holótipo fêmea, comprimento 25,2mm; (2) Charoides pepoata, sp.n., holótipo fêmea, comprimento $17,1 \mathrm{~mm}$.

Discussão. Neoptychodes cosmeticus assemelha-se mais a N. cretatus (Bates, 1872) pela ausência de faixa branca contínua junto da sutura elitral. Esta espécie foi figurada por BATES (1880, est. 5, fig. 7) e por Dillon \& Dillon (1941, est. 3, fig. 22) e ocorre na Nicarágua, Costa Rica e Panamá. O padrão de colorido dos élitros em $N$. cretatus consiste em três manchas irregulares de pubescência esbranquiçada, separadas entre si e localizadas junto à margem, portanto, bem diferente do padrão de $N$. cosmeticus. 
Neoptychodes cosmeticus não pode ser confundida com N. candidus (Bates, 1885) da qual examinamos uma fêmea proveniente de El Diviso, Colômbia (MZSP), pelo tegumento vermelho-acastanhado, pela franja de pêlos muito mais densa no lado inferior do antenômero III; pelas granulações da base dos élitros muito mais densas e anastomosadas e pela ausência de pubescência branca densa nos mesepisternos e nos metepisternos.

\section{Onciderini}

\section{Charoides pepoata, sp.n.}

Fig. 2

Etimologia. Tupi; pepó = asa; atã = dura, alusivo à consistência dos élitros.

Fêmea. Tegumento preto, mais acastanhado nos élitros. Tegumento esbranquiçado: terço basal dos antenômeros III e IV, bases dos antenômeros V-XI e dois terços basais dos tarsômeros V. Fronte com pubescência amarelada rala, mais concentrada em duas máculas ao nível do meio; pontos rasos e densos. Lobos oculares inferiores tão longos quanto as genas. Dorso da cabeça com pubescência amarelada, densamente marmorada de castanho. Antenas atingem o sexto apical dos élitros. Escapo (comprimento 3,4mm) praticamente tão longo quanto o antenômero III (comprimento 3,3 $\mathrm{mm}$ ); pubescência amarelada, variegada de castanho principalmente na clava. Pronoto com cinco tubérculos individualizados; pubescência castanha entremeada por pubescência amarelada. Lados do protórax sem tubérculo. Processo prosternal com quilha transversal. Escutelo profundamente emarginado na borda posterior; lados com pubescência amarelada. Élitros com pubescência acastanhada quase uniforme, mais variegada com pubescência amarelada em direção ao ápice; faixa estreita, de pubescência amarelada, ao nível do meio, oblíqua em sentido descendente da margem para a sutura, que não toca ambas. Úmeros bem projetados, arredondados. Esternos torácicos com pubescência amarelada. Centro dos urosternitos com pubescência castanha, algo variegada por pubescência amarelada; lados dos urosternitos com densa pubescência amarelo-alaranjada, entremeada por alguns pontos castanhos. Fêmures com pubescência amarelada variegada por pontos de pubescência castanha, mais evidentes na metade apical dos médios e em dois anéis nos posteriores, um no meio, outro ante-apical. Tíbias amareladas variegadas por pontos de pubescência castanha; os dois terços apicais das metatíbias com pubescência amarelada. Tarsômeros revestidos por pubescência amarelada.

Dimensões holótipo fêmea. Comprimento total 17,1. Protórax: comprimento 2,9; maior largura 4,6. Élitros: comprimento 13,0; largura umeral 8,0.

Holótipo fêmea, Bolívia, Nor Yungas: La Paz (Carrasco), 14.IX.1989, Guerra leg. (MZSP).

Discussão. Embora a maioria das espécies de Charoides apresente nos élitros uma faixa de pubescência clara oblíqua em sentido descendente da margem para a sutura, em nenhuma a faixa é tão estreita e tão regular como em C. pepoata. Além disso, nesta espécie o escutelo é profundamente emarginado na borda posterior. 
Pela chave de DiLlon \& Dillon (1945), C. pepoata reúne-se ao grupo de espécies com processo prosternal elevado entre as procoxas, protórax sem tubérculo lateral e élitros com faixa mediana distinta, assemelhando-se mais a C. pulla Dillon \& Dillon. Distingue-se de C. pulla, além do padrão simples do colorido geral, pelos élitros densamente pontuados na metade basal, com gibosidades centro-basais pouco salientes e pelas tíbias variegadas por pontos de pubescência castanha.

\section{Venustus analogus, sp.n.}

Fig. 4

Macho. Tegumento de maneira geral avermelhado; tegumento preto a castanho-escuro: base do escapo, terço apical do antenômero III; metade apical dos antenômeros IV-X; grande área triangular na metade basal de cada élitro; dois terços basais dos profềmures; anel nos meso- e metafêmures. Pubescência amarelo-sujo reveste: cabeça (mais esparsa na fronte); escapo, pedicelo, dois terços basais do antenômero III, terço basal do IV, metade basal de V-X; protórax (mais concentrada nos lados do pronoto); em áreas curtas na base dos élitros; faixa oblíqua em sentido descendente da margem para a sutura atrás da área triangular escura; em três faixas estreitas, longitudinais, no dorso do terço apical; na face ventral e nas pernas. Caracteres morfológicos como em V. zeteki (Dillon \& Dillon 1945: 115-117).

Dimensões, respectivamente macho/fêmea. Comprimento total 11,4/12,1; largura umeral 5,1/5,3.

Holótipo macho. ColôMBIA: Moritz leg. (MZSP). Parátipo fềmea, sem procedência, provavelmente mesmo dados do holótipo (MZSP).

Discussão. Em 1979, um dos autores (URM), recebeu para identificar os Onciderini do MNHU. Dentre esse material, alguns indivíduos rotulados: "Columbien, Moritz", junto com outros, sem procedência, mas que devem pertencer à mesma série. Âquela época, foram identificados como Venustus zeteki Dillon \& Dillon e um casal foi retido para o MZSP. Recebemos recentemente os longicórneos de MHNB onde se encontram dois exemplares de Venustus que concordam plenamente com a descrição e a figura originais de $V$. zeteki. Pudemos verificar então que a identificação de Martins, em 1979, estava equivocada e o material do MNHU pertence a $V$. analogus, sp.n.

$V$. analogus difere de $V$. zeteki pelo tegumento avermelhado e pelo padrão do colorido elitral (Figs 3-4). Em $V$. analogus a pubescência do terço apical dos élitros está organizada em estreitas faixas longitudinais, inexistentes em $V$. zeteki.

\section{Venustus zeteki Dillon \& Dillon, 1945}

Fig. 3

Venustus zeteki Dillon \& Dillon, 1945: 116, est. 5, fig. 6 .

Material examinado. ColôMBIA, Bolivar: Zambrano (Hacienda Monterrey, $9^{\circ} 45^{\prime} \mathrm{N}, 74^{\circ} 45^{\prime} \mathrm{W}, 10 \mathrm{~m}$, malaise ${ }^{\circ}$ 9, "lata aerea"), macho, 11.X.1993, F. Fernandez leg. (MHNB N4417); idem, macho, 28.XII.1993, F. Fernandez leg. (MHNB $\left.\mathrm{N}^{\circ} 4434\right)$. 

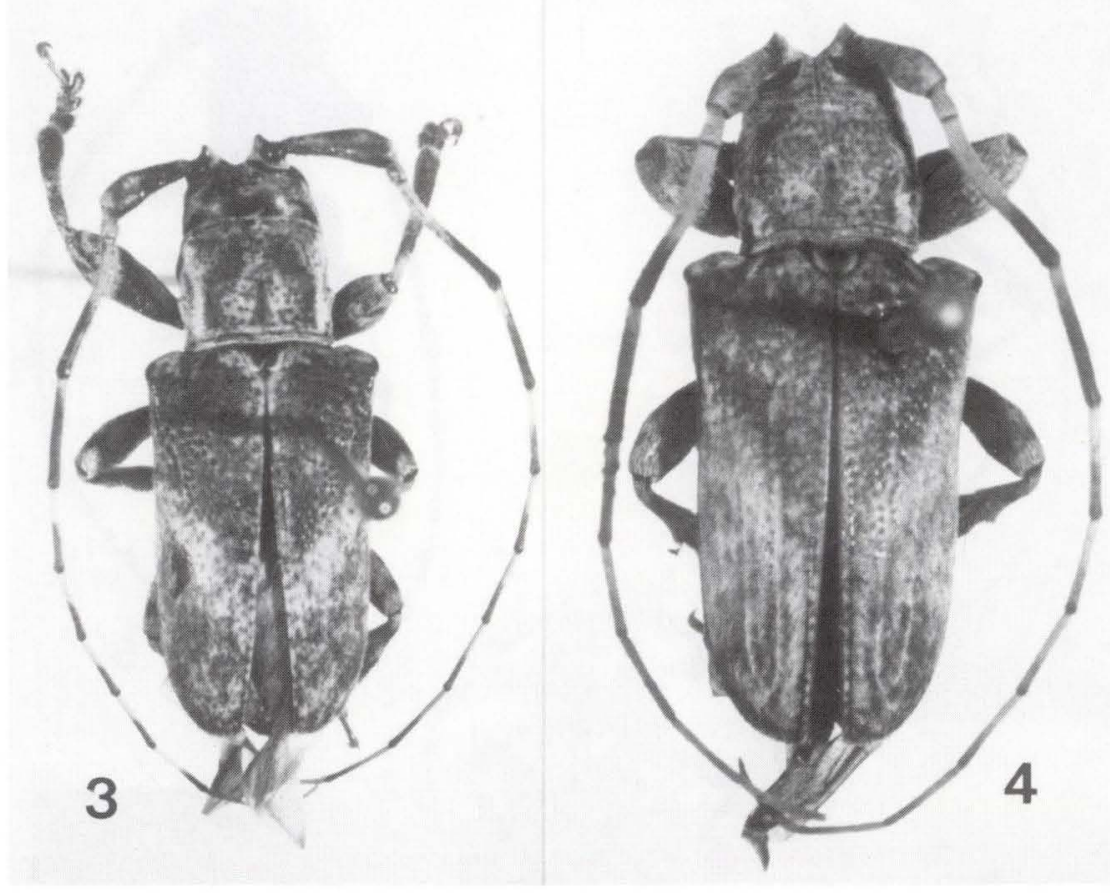

Figs 3-4. (3) Venustus zeteki Dillon \& Dillon, 1945, macho de Zambrano, Bolivar, Colômbia; (4) V. analogus, sp.n., holótipo macho, comprimento $11,4 \mathrm{~mm}$.

\section{Oncideres mirim, sp.n.}

Fig. 10

Macho. Tegumento castanho-avermelhado. Fronte muito fina e densamente pontuada (40x); pubescência alaranjada, rala, adensada junto à margem interna dos olhos. Lobos oculares inferiores desenvolvidos com aproximadamente o quíntuplo do comprimento da gena. Região posterior aos olhos com densa pubescência alaranjada. Vértice com uma faixa transversal indistinta de pubescência alaranjada entre os tubérculos anteníferos. Antenas com pubescência alaranjada, esparsa e uniforme; atingem as extremidades elitrais aproximadamente no ápice do artículo VII. Pronoto com pubescência alaranjada e cinco calosidades desenvolvidas, pretas e glabras. Tubérculo lateral do protórax preto, glabro. Metade superior dos mesepisternos e lados do metasterno com faixa de pubescência alaranjada densa. Élitros com pubescência alaranjada uniforme; úmeros largamente glabros; metade basal com tubérculos pretos, grandes e próximos (aproximadamente 12 por élitro); metade apical com pontos circundados por grandes manchas castanhas glabras gradualmente menores para o ápice. 


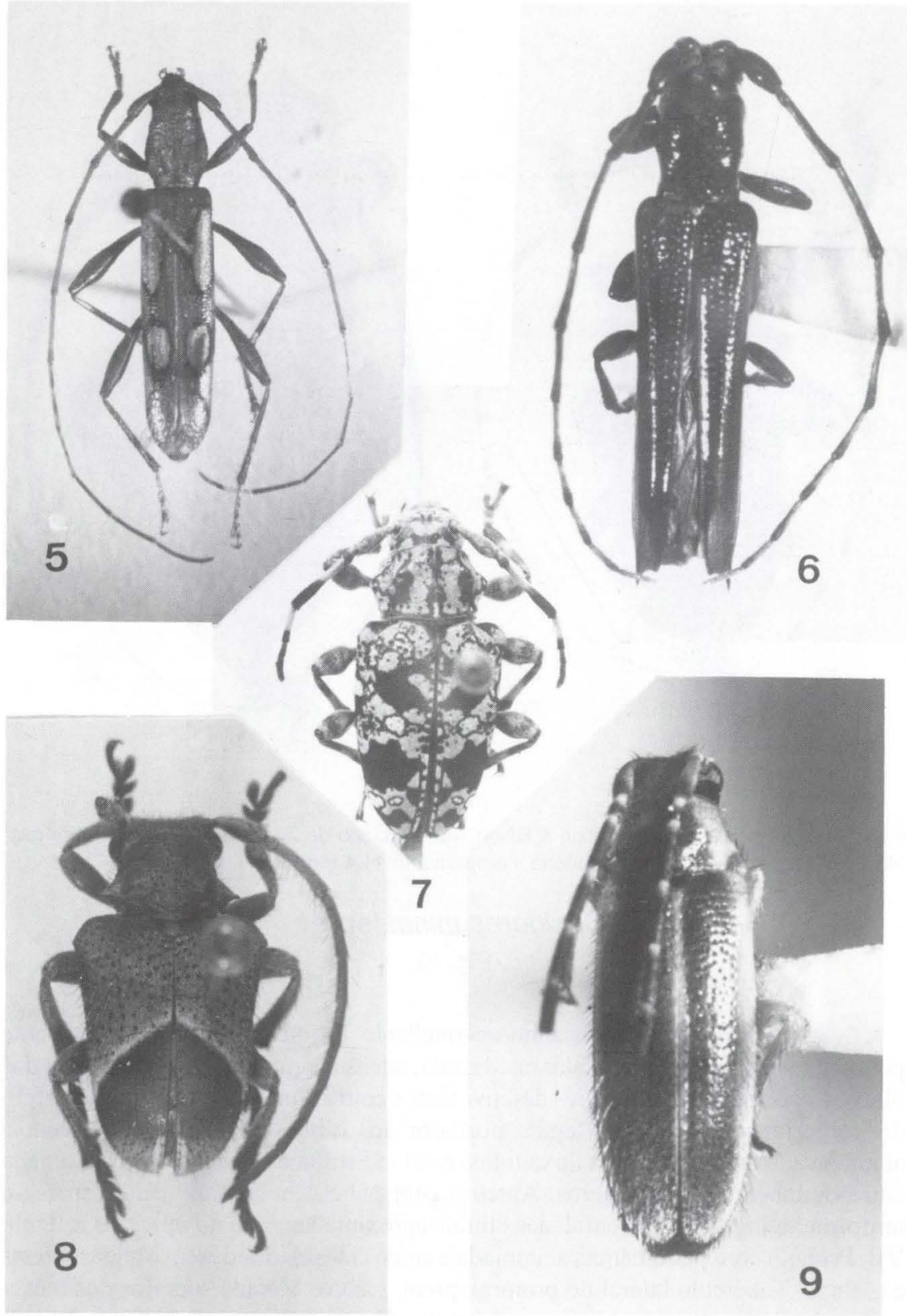

Figs 5-9. (5) Ectenessa andrei, sp.n., parátipo macho, comprimento 11,3mm; (6) Camixaima beraba, sp.n., holótipo macho, comprimento $9,4 \mathrm{~mm}$; (7) Acakyra iaguara, sp.n., parátipo fêmea, comprimento $11,3 \mathrm{~mm}$; (8) Compsosoma monnei, sp.n., holótipo macho, comprimento 13,0mm; (9) Lustrocomus paraensis, sp.n., holótipo macho, comprimento 5,7mm. 
Dimensões. Comprimento total 7,3. Protórax: comprimento 1,4; maior largura, 1,9. Élitros: comprimento 5,3; largura umeral 2,4.

Holótipo macho. Brasil, Pará: Carajás (Serra Norte), 5-15.IV.1983, M. Miles leg. (armadilha luminosa), (MZSP).

Discussão. O. mirim assemelha-se a O. manauara Martins \& Galileo, 1995 pelo aspecto dos tubérculos glabros dos élitros. Distingue-se pela pubescência elitral alaranjada, uniforme e lados do metasterno ocupados por faixa de pubescência alaranjada. Além disso as dimensões são menores e os tubérculos da metade basal dos élitros são consideravelmente maiores e menos numerosos. Em $O$. manauara existe vestígio de faixa transversal de pubescência branca nos élitros e os lados do metasterno são brancos. O. mirim não pode ser confundida com $O$. tuberculata Thomson, 1868 e O. minuta Thomson, 1868 por não apresentar máculas de pubescência branca nos élitros.

\section{Compsosomatini}

\section{Compsosoma monnei, sp.n.}

Fig. 8

Macho. Tegumento preto; tegumento avermelhado: élitros, coxas, prosterno, mesosterno e centro do metasterno. Pubescência branca ou esbranquiçada reveste: fronte, antenas (exceto artículos apicais); faixa oblíqua em sentido descendente da sutura para a margem no meio dos élitros; faixa longitudinal junto da sutura na declividade apical; mancha nos mesepisternos; ponta inferior dos mesepimeros; dois terços anteriores dos metepisternos; lados do metasterno; lado externo das protíbias; bases das meso- e metatíbias. Restante da pubescência alaranjada. Região entre as faixas oblíquas elitrais acastanhada, conforme a incidência da luz. Regiões látero-anteriores dos élitros (abaixo dos úmeros), mesepisternos, mesepimeros, metepisternos e lados do metasterno com pubescência castanho-escura. Tarsos pretos. Cabeça e pronoto pontuados. Terço anterior dos élitros com grânulos glabros, abundantes; metade apical finamente pontuada. Mesosterno sem tubérculo. Centro do metasterno esparsamente pontuado.

Dimensões holótipo macho. Comprimento total 13,0. Protórax: comprimento 3,3; maior largura 5,1. Élitros: comprimento 9,1; largura umeral 7,0.

Holótipo macho. Bolívia, Cochabamba: Villa Tunari, 10-25.XI.1992, C. Arriagada leg. (MZSP).

Discussão. A única espécie de Compsosoma que apresenta faixa longitudinal de pubescência branca junto da sutura na região apical dos élitros é C. mniszechii Thomson, 1857, registrada até o momento para o Brasil (Amazonas) e o Peru (Junin) (Monné 1980; Monné \& GiesberT 1993). C. monnei distingue-se de C. mniszechii, pela ausência de manchas de pubescência castanho-escura nos lados do pronoto e pela menor densidade de tubérculos glabros na metade anterior dos élitros. Segundo MonNé (1980: 89), em C. mniszechii o terço basal dos élitros apresenta grânulos grandes, elevados e densos o que pudemos confirmar pelo exame do diapositivo do holótipo obtido por Jesus S. Moure no MNHN. 

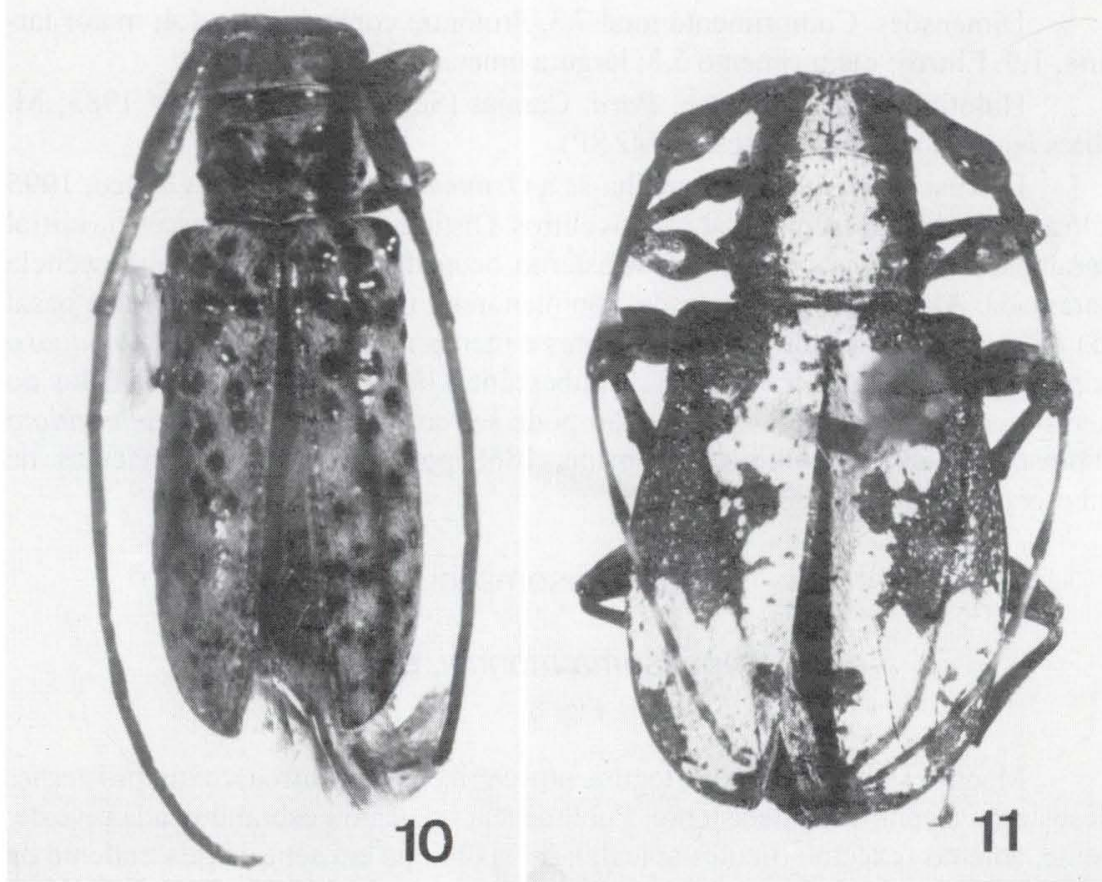

Figs 10-11. (10) Oncideres mirim, sp.n., holótipo macho, comprimento 7,3mm; (11) Phacellocera susua, sp.n., holótipo fêmea, comprimento $11,3 \mathrm{~mm}$.

\section{Desmiphorini}

\section{Desmiphora auatinga sp.n.}

Fig. 12

Etimologia. Tupi, áua $=$ cabelo, ting $a=$ branco, alusivo aos pincéis da metade apical dos élitros.

Macho. Cabeça com tegumento vermelho-acastanhado, revestida por pubescência amarelada; região dorsal com dois fascículos de pêlos pretos. Lobos oculares superiores com cinco fileiras de omatídios; lobos oculares inferiores com o triplo do comprimento da gena. Escapo e pedicelo com tegumento vermelho-acastanhado. Flagelômeros amarelo-alaranjados; franja de pêlos no lado interno, densa, mas não compacta. Protórax com tegumento castanho-avermelhado; lados revestidos por densa pubescência branca cuja borda interna converge para o centro anterior onde se funde com a faixa oposta. Centro da borda anterior do pronoto com fascículo de pêlos brancos longos; dois fascículos de pêlos pretos ao nível do dorso do quarto anterior do pronoto; disco pronotal esparsamente pubescente, forte e densamente pontuado junto aos pincéis pretos. Espinho lateral do protórax pequeno, mas 
evidente. Centro da margem posterior do pronoto com fascículo de pêlos castanhoclaros, pouco evidente, estendendo-se sobre o escutelo. Tegumento elitral avermelhado no dorso e acastanhado nos lados; pubescência, de maneira geral, amarelada. Cada élitro com: no centro-basal, fascículo curto, de pêlos pretos; no terço apical com quatro fascículos de pêlos brancos longos. Pubescência branca nos élitros: faixa estreita, curva, que se inicia sobre os úmeros e atinge o friso marginal onde se volta obliquamente para o dorso, terminada longe da sutura; faixa estreita oblíqua do fascículo centro-basal à sutura; faixa oblíqua que se inicia na margem e envolve os fascículos brancos mais anteriores do terço apical; faixa semelhante que envolve os fascículos posteriores do terço apical; região entre fascículos com pubescência branca. Presença de mancha de tegumento preto entre os fascículos brancos, dorsais do quarto e do quinto apical. Região lateral dos élitros com pontos grossos, profundos e esparsos. Processos pro- e mesosternal sem tubérculos. Fêmures com tegumento avermelhado e anel central preto, revestidos por pubescência branca. Tíbias e tarsos com tegumento alaranjado. Face ventral com tegumento predominantemente preto, revestida por pubescência branca, mais adensada nos lados do metasterno.
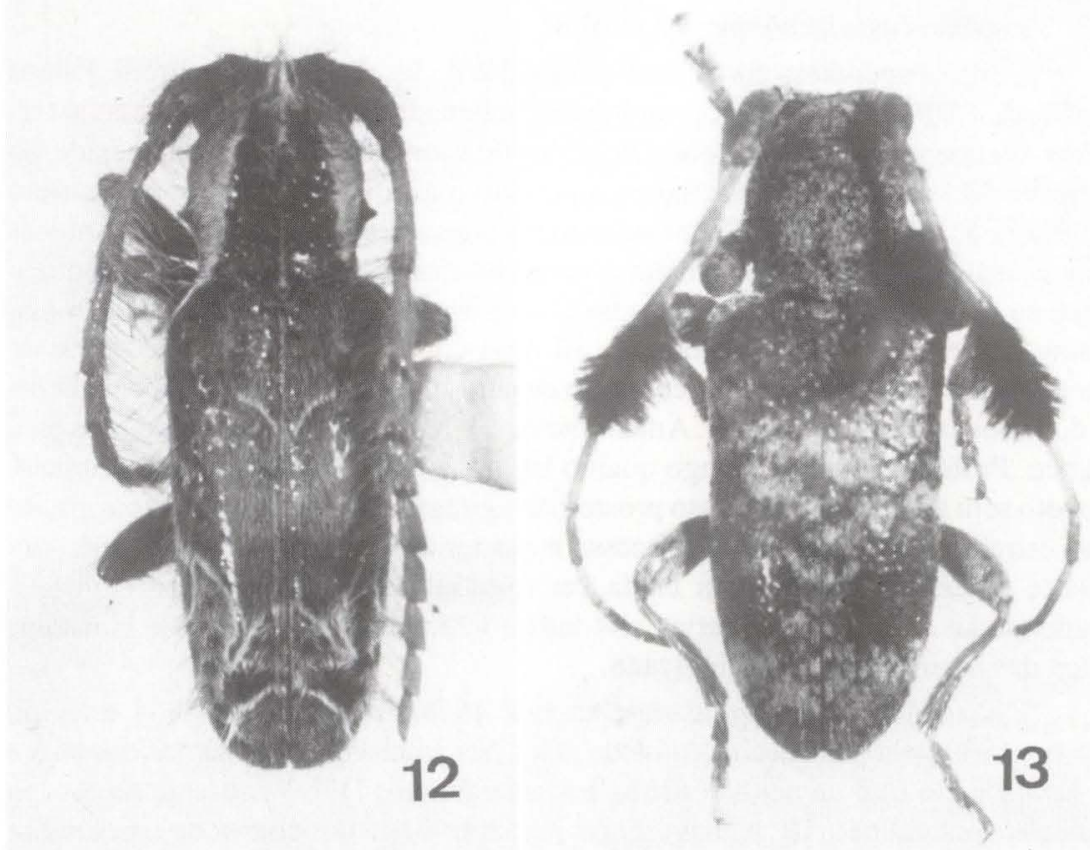

Figs 12-13. (12) Desmiphora auatinga, sp.n., holótipo fêmea, comprimento 6,5mm; (13) lurubanga arixi, sp.n., holótipo macho, comprimento $6,6 \mathrm{~mm}$. 
Dimensões macho. Comprimento total 6,4-6,5. Protórax: comprimento 1,61,7; maior largura 1,8-1,9. Élitros: comprimento 4,4-4,5; largura umeral 2,1.

Holótipo macho e parátipo macho. EQUADOR, El Oro: Machala $(1 \mathrm{~km} \mathrm{~N}$, 50m), 19.II.1981, H. Howden leg. (CMNC, MZSP).

Discussão. Pertence ao grupo de espécies com pronoto largamente branco aos lados. Distingue-se de $D$. scapularis Bates, 1885 pela ausência de mancha de pubescência amarelada dorsal na região sutural da base dos élitros; pelo fascículo centro-basal dos élitros preto; pela presença de faixas estreitas de pubescência branca na metade anterior dos élitros e pelos pincéis de pêlos brancos no terço apical dos élitros (em $D$. scapularis existem três pincéis em cada élitro). Distingue-se de D. cirrosa Erichson, 1847 pelas menores dimensões e pela ausência de tubérculo no processo prosternal; além disso em $D$. cirrosa os fascículos de pêlos da cabeça são brancos.

\section{lurubanga, gen $\mathbf{n}$.}

Etimologia. Tupi, iurú $=$ boca, banga $=$ torto, alusivo à anormalidade dos palpos maxilares e labiais.

Espécie-tipo, Iurubanga arixi sp.n.

Corpo e apêndices com abundantes pêlos eretos. Cabeça não retrátil. Palpos maxilares e labiais securiformes no macho, aciculados na fêmea. Fronte convexa. Olhos finamente facetados; lobos oculares inferiores reduzidos com metade do comprimento da gena; lobos oculares superiores mais distantes entre si que o triplo da largura de um lobo. Tubérculos anteníferos pouco projetados, distantes. Antenas com 11 artículos, tão longas quanto o corpo no macho, apenas mais curtas que o corpo na fêmeas. Escapo cilíndrico, sem cicatriz apical, aproximadamente tão longo quanto o antenômero III. Antenômero III mais curto que o IV. Metade apical do antenômero IV e antenômero $\mathrm{V}$ com tufo de pêlos longos e densos; o IV com cerca do dobro do comprimento do V. Antenômeros VI-XI gradualmente mais curtos para o ápice. Protórax quase tão longo quanto largo; lados com espinho curto no meio. Pronoto sem tubérculos. Processo prosternal regularmente convexo, no meio, muito mais estreito do que a procoxa. Processo mesosternal com lados convergentes para a parte posterior. Élitros com crista centro-basal muito elevada; extremidades arredondadas. Mesocoxas abertas nos lados. Fêmures pedunculados e clavados. Sulco das mesotíbias apenas indicado.

Discussão. Iurubanga assemelha-se a Atelodesmis Buquet, 1857 e Esmia Pascoe, 1859 pela presença de tufos de pêlos nas antenas. Difere de Atelodesmis e de Esmia: pelo tufo de pêlos restritos aos antenômeros IV e V, ausente no escapo pedicelo e antenômero III; pela presença, no centro-basal dos élitros, de crista muito elevada; pelo último artículo dos palpos maxilares e dos labiais securiforme nos machos; pelo processo mesosternal mais estreito que a metade da largura da mesocoxa. 


\section{lurubanga arixi, sp.n.}

Fig. 13

Etimologia. Tupi; arixi $=$ elegante.

Cabeça com tegumento castanho-avermelhado revestida por pubescência esbranquiçada; com pontos grande e profundos. Escapo e pedicelo com tegumento avermelhado. Flagelômeros III, metade basal do IV , VI (exceto extremo apical) e VIII com tegumento amarelo-esbranquiçado; metade apical do IV, V, VII e IX a XI com tegumento avermelhado. Metade apical dos antenômeros IV e V intumescidos. Protórax com tegumento castanho-avermelhado revestido por pubescência esbranquiçada moderadamente densa; profunda e densamente pontuada. Élitros castanhoavermelhados revestido por pubescência esbranquiçada marmorada de castanho; mancha acastanhada no centro do terço basal e faixa acastanhada subtransversal que não atinge a sutura ao nível do terço apical. Fêmures castanho-avermelhados com bases amareladas, revestidos por pubescência esbranquiçada, entremeada por pontos contrastantes. Tíbias amareladas com base castanho-avermelhadas. Face ventral castanho-avermelhada revestida por pubescência esbranquiçada entremeada por pontos contrastantes.

Dimensões macho/fêmea respectivamente. Comprimento total 6,6/ 6,0. Protórax: comprimento 1,6/1,5; maior largura 2,0/1,8. Élitro: comprimento 4,7/4,3; largura umeral 2,5/2,1.

Holótipo macho. BRAsil, Santa Catarina: São Bento do Sul (Rio Vermelho), XI.1950, Dirings leg. (MZSP). Parátipos: fềmea, Paraná: Bocaiuva (250'S 4904'W, 1000m), XII.1973, F. Plaumann leg. (MZSP); fêmea; Santa Catarina: São Bento do Sul (Rio Vermelho), I. 1944, A. Maller leg. (MNRJ); macho, idem, XII. 1957 (MNRJ); fêmea, idem, II.1965 (MNRJ).

\section{Acanthoderini}

\section{Acakyra, gen.n.}

Etimologia. Tupi, $a c a=$ chifre $k y r a=$ gordo, alusivo ao espessamento do antenômero III.

Espécie-tipo, Acakyra iaguara, sp.n.

Fronte tão larga quanto longa. Tubérculos anteníferos aplanados, distantes. Olhos divididos, finamente facetados; lobos oculares inferiores tão longos quanto a metade do comprimento das genas. Antenas (fêmea) com onze artículos, atingem aproximadamente a metade dos élitros. Escapo piriforme sem sulco no lado superior da base, mais curto que o antenômero III e apenas mais longo que o IV. Antenômero III com o dobro do comprimento do IV, fortemente intumescido na metade apical. Antenômero IV não intumescido no ápice. Antenômeros V-XI muito curtos; em conjunto apenas mais longos que o antenômero III. Protórax mais largo do que longo; lados com espinho central. Pronoto com dois tubérculos látero-anteriores e quilha longitudinal central, menos projetada que os tubérculos. Escutelo não enta- 
lhado na borda apical. Élitros com curta carena centro-basal, não prolongada pelo dorso; região dorsal regularmente convexa; carena fina, paralela e próxima ao friso sutural do terço apical até a extremidade; ápices desarmados. Processo prosternal com dois tubérculos, truncado posteriormente. Processo mesosternal largo, com dois tubérculos, truncado anteriormente. Fêmures pedunculados e clavados. Tíbias anteriores (fêmea) não modificadas, levemente alargadas para a extremidade. Mesotíbias com sulco.

Discussão. Acakyra caracteriza-se pela fórmula antenal e pela ausência de carena dorsal nos élitros. O antenômero III é fortemente intumescido na metade apical mas não apresenta tufo de pêlos longos; o IV não tem modificações apicais e os restantes são curtíssimos.

Nos gêneros Discopus Thomson, 1864 e Plagiosarus Bates, 1880 as antenas apresentam tufos de pêlos no antenômero III e os élitros têm carena dorsal. Em Tetrasarus Bates, 1880 e Paradiscopus Schwarzer, 1930 as extremidades dos antenômeros III e IV apresentam tufo de pêlos no lado interno, o III não é intumescido na metade apical, os artículos apicais não são reduzidos e as antenas quase atingem as extremidades elitrais. Em Pteridotelus White, 1855 os flagelômeros basais não apresentam modificações e os apicais são subserreados.

\section{Acakyra iaguara, sp.n.}

Fig. 7

Etimologia. Tupi, iaguara $=$ onça, alusivo ao padrão de colorido.

Fêmea. Tegumento de maneira geral castanho-avermelhado; tegumento preto: face ventral da cabeça, metade apical do antenômero III, quarto apical do antenômero IV, anel nos fêmures, ápice das tíbias e quase toda a face ventral; tegumento amarelado: base dos antenômeros III e IV, anel central nas tíbias e tarsos. Fronte com pubescência amarela, duas manchas de pubescência branca: uma junto ao clípeo e outra central delimitadas por estreita borda de pubescência acastanhada. Pubescência de maneira geral amarelada. Pubescência castanho-escura: faixas transversais entre os tubérculos anteníferos e atrás dos lobos oculares superiores no dorso da cabeça; três faixas longitudinais no pronoto: uma central alargada anteriormente e sobre a gibosidade, duas laterais; dorso anterior dos úmeros; três manchas em cada élitro (uma dorsal, ao nível do terço anterior, levemente oblíqua em sentido descendente da margem para a sutura; uma transversal, com bordas irregulares, mais distante da sutura e fundida à margem, logo atrás do meio; uma menor, transversal, ante-apical). Cada élitro com cinco manchas pequenas, de pubescência branca, circundadas estreitamente por pubescência castanha (duas dorsais perto da base; uma centro-dorsal, entre as faixas castanhas e duas subapicais também entre as faixas castanhas). Metade anterior dos élitros com pontos e manchas castanhos entre a pubescência amarela. Friso sutural com manchas alternadas castanhas e brancas. Face ventral com pubescência amarela subuniforme; lados do metasterno com mancha transversal glabra.

Dimensões fêmea. Comprimento total 12,4-12,7. Protórax: comprimento 2,6-2,7; maior largura 4,5-4,8. Élitros: comprimento 8, 1-8,2; largura umeral 5,4-5,8.

Revta bras. Zool. 13 (2): 291 - 311, 1996 
Holótipo fềmea, ColômBIA, Valle del Cauca: Bajo Calima (en bosque), XII. 1952, Gallego leg. (UNCM); parátipo fêmea, Bolo Abajo, I.1965, R. Vélez leg. (en bosque), (MZSP).

Discussão. Nas duas antenas do parátipo, os antenômeros VI-XI apresentamse fundidos em três artículos na antena esquerda e em quatro na direita, portanto as antenas apresentam respectivamente 8 e 9 artículos.

\section{Anisocerini}

\section{Fredlanella, nom.n.}

Taperinha Lane, 1964: 179 non Linnavuori, 1959: 188 (Homoptera, Deltocephalinae).

O nome Taperinha Lane, 1964 estava pré-ocupado por LINNAVUORI (1959) para um gênero de Homoptera, Cicadellidae, Deltocephalinae.

\section{Phacellocera palliata (White, 1855), comb.n.} Anisocerus palliatus White, 1855: 407; Monné, 1994: 10 (cat.).

O exame de material proveniente da Costa Rica (MZSP) permitiu transferir esta espécie para Phacellocera Laporte, 1840. Os gêneros relacionados com Phacellocera e Anisocerus Lepeletier \& A.-Serville, 1830 reúnem miscelânea de formas e esta transferência pode ser provisória, até que uma revisão da tribo possa ser concluída. Como a nova espécie que abaixo descrevemos é semelhante a $P$. palliata, julgamos necessário transferí-la para o melhor estabelecimento de comparações.

\section{Phacellocera susua, sp.n.}

Fig. 11

Etimologia. Tupi, susuá = inchaço; alusivo ao espessamento apical do antenômero III.

Fêmea. Tegumento preto. Pubescência branca, compacta, reveste: fronte (entremeada por abundantes pontuações e asperezas que lhe conferem aspecto marmorado); faixa larga do vértice ao occipício; faixa longitudinal, larga, no meio do pronoto; escutelo; faixa longitudinal, com bordas irregulares, junto da sutura elitral que vai da base ao terço apical onde termina em faixa transversal, irregular, que atinge e envolve quase todo quarto apical; face ventral do corpo marmorada por pontos escuros; anel no antenômero III à frente da dilatação apical; metade basal dos antenômeros IV-X; pernas (exceto extremidades das tíbias e tarsômeros V). Lobos oculares inferiores tão longos quanto metade do comprimento das genas. As antenas atingem as extremidades elitrais. Antenômero III fortemente intumescido no lado interno do ápice; o IV sem modificação apical. Pronoto com dois tubérculos pequenos, brilhantes, situados ao nível do terço anterior. Gibosidade centro-basal dos élitros pouco manifesta, com grânulos brilhantes que também ocupam os úmeros. Metade apical dos élitros sem depressões. Último urosternito com faixa centro-longitudinal glabra. 
Dimensões holótipo fềmea. Comprimento total 11,3. Protórax: comprimento 2,3; maior largura 3,6. Élitros: comprimento 7,8; largura umeral 4,7.

Holótipo fêmea. Equador, Pichincha: Rio Palenque Research Station, II.1983, M. Sharkey \& L. Masner leg. (malaise) (CNCI).

Discussão. O gênero Phacellocera Laporte, 1840 (espécie-tipo por monotipia $P$. scopulicornis Laporte, 1840 = Lamia plumicornis Klug, 1825), reúne espécies morfologicamente bastante diversas e a eventual revalidação dos seus sinônimos deve ser examinada.

Phacellocera susua assemelha-se pela fórmula antenal a $P$. palliata (White, 1855); P. genalis Aurivillius, 1908; P. buquetii Guérin-Méneville, 1844 e P. batesii Pascoe, 1858. Nestas espécies apenas o antenômero III é fortemente intumescido no lado interno do ápice. Pelo aspecto robusto e compacto do corpo assemelha-se mais a $P$. palliata mas difere: pela pubescência de fundo preta; pela faixa centrolongitudinal branca do dorso da cabeça e do pronoto praticamente sem pontos; pela pontuação elitral muito mais esparsa, com apenas alguns pontos contrastantes nas áreas de pubescência branca; pelo quinto apical dos élitros quase inteiramente revestido por pubescência branca.

\section{Hemilophini}

\section{Neomoema, nom.n.}

Moema Martins \& Galileo, 1992: 594 non Costa, 1989: 223

Moema está pré-ocupado por gênero de peixes (Rivulidae) proposto por Costa (1989).

\section{Falsamblesthiini}

\section{Camixaima, gen.n.}

\section{Espécie-tipo, Camixaima beraba sp.n.}

Etimologia. Tupi, camixáima $=$ nu, alusivo à falta de pubescência corporal.

Macho. Corpo com tegumento brilhante, glabro, na face dorsal. Ápice das mandíbulas fracamente emarginado. Fronte estreita, aproximadamente tão longa quanto larga. Olhos desenvolvidos; lobos separados entre si por cinco fileiras de omatídios; lobos oculares superiores mais próximos entre si do que a largura de um lobo; lobos oculares inferiores com o quádruplo do comprimento da gena. Tubérculos anteníferos bem projetados, próximos na base. Antenas mais longas que o corpo. Escapo subpiriforme, mais largo ao nível do meio, mais curto que o antenômero III. Antenômero IV, o mais longo, com 1,3 vezes o comprimento do III. Protórax mais longo do que largo, acentuadamente constrito na base; lados sem espinho. Pronoto convexo, sem tubérculos. Processo mesosternal sem tubérculo. Extremidades elitrais emarginadas, projetadas no ângulo sutural e espinhosas no ângulo marginal. Profêmures robustos e fusiformes. Mesofêmures com pedúnculo basal curto. Metafêmures pouco mais delgados, subfusiformes. Sulco das mesotí- 
bias pouco profundo. Último urosternito com borda apical transversamente truncada.

Discussão. Camixaima caracteriza-se pela ausência de pubescência praticamente em todo o corpo; pelos lados do protórax desprovidos de espículo ou tubérculo e acentuadamente constritos na base.

Na chave para os gêneros de Falsamblesthiini (MARTINS \& GALILEO 1989), Camixaima insere-se no dilema 11 onde separam-se gêneros com protórax desarmado aos lados: Bactriola Bates, 1885, Pseudogisostola Fontes \& Martins, 1977 e Obereoides Fisher, 1938. Difere de Bactriola, além dos caracteres mencionados acima, pelas maiores dimensões, pelas extremidades elitrais entalhadas, projetadas no ângulo sutural e espinhosas no ângulo externo. Difere de Pseudogisostola também pela fórmula antenal; neste gênero os antenômeros III e IV têm comprimentos subiguais.

\section{Camixaima beraba, sp.n.}

Fig. 6

Etimologia. Tupi, beraba $=$ brilhante, alusivo ao aspecto geral .

Macho. Tegumento castanho-escuro a castanho-avermelhado, glabro, muito brilhante. Antenômeros IV-XI com terço apical escurecido. Pubescência ausente na face dorsal do corpo. Fronte com escassa pubescência branca, mais concentrada nas bordas dos olhos e nas genas. Escapo com pubescência branca, muito esparsa. Bases dos flagelômeros com pubescência branca; pêlos internos esparsos. Pronoto com pontos grossos e esparsos. Élitros com pontos grossos na metade basal, alinhados em fileiras; metade apical praticamente lisa. Pubescência branca na face ventral recobre: prosterno, mesepimeros, mesepisternos, metepisternos; lados do metasterno e dos urosternitos e fềmures com pubescência mais esparsa. Tarsos densamente pubescentes.

Dimensões holótipo macho. Comprimento total 9,4. Protórax: Comprimento 1,8; maior largura 1,5. Élitros: comprimento 6,7; largura umeral 2,1.

Holótipo macho. EQUADOR, Napo: Tena ("vicinity", 500m), 5-10.VII.1976, S. \& J. Peck leg. (CNCI).

\section{Calliini}

\section{Callisema iucaua, sp.n.}

Etimologia. Tupi, iucáua $=$ espinhento, alusivo à forma das extremidades elitrais,

Macho. Tegumento avermelhado escuro. Pubescência de maneira geral esbranquiçada. Fronte com pubescência moderadamente densa. Tubérculos anteníferos projetados; região entre os tubérculos com área glabra, elíptica, alongada, delimitada por sulco raso. Lobos oculares superiores com seis fileiras de omatídios, mais próximos entre si do que a largura de um lobo. Cabeça com dorso pubescente e região central com pontos evidentes, densos, glabros e profundos. Antenas 
atingem a extremidade dos élitros aproximadamente no ápice do artículo IX. Flagelômeros unicolores. Protórax esparsamente pubescente; pronoto com três faixas longitudinais de pubescência mais densa: uma centro-dorsal e duas mais estreitas laterais. Escutelo densamente pubescente. Pubescência elitral mais aglutinada em áreas irregulares, principalmente na metade apical; pontos da base dos élitros tuberculados. Extremidades elitrais oblíquas, prolongadas em espinho curto no lado externo. Tubérculo mesosternal muito projetado. Metafêmures com pontos contrastantes. Lados do metasterno esparsamente pontuados. Lados dos urosternitos com pubescência e pontos contrastantes.

Dimensões. Comprimento total 9,6. Protórax: comprimento 1,5; maior largura 1,9. Élitros: comprimento 7,2; largura umeral 2.6.

Holótipo macho: PERU, Junin: Satipo, III.1941 (MNRJ).

Discussão. MARTINS \& GALILEO (1990) apresentaram chave para reconhecimento das três espécies de Callisema Martins \& Galileo, 1990 então conhecidas. GALILEO \& MARTINS (1992) acrescentaram ao gênero C. elongata. Justifica-se, portanto, uma atualização da chave para a inclusão de C. elongata e C. iucaua.

\section{Chave para as espécies de Callisema}

1. Élitros com tegumento bicolor, toda a declividade lateral mais clara do que o

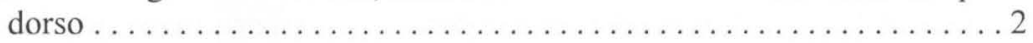

- Élitros com tegumento unicolor . . . . . . . . . . . . . . . . . . 3

2. Regiões laterais dos élitros avermelhadas, inclusive úmeros, quase atingem o ápice; extremidades elitrais obliquamente truncadas; abdômen, lados do metasterno e fềmures com pontos glabros, grandes e evidentes. Brasil (Mato Grosso, Goiás) . . . . . . . . . . . consortium Martins \& Galileo, 1990

- Regiões laterais dos élitros amareladas, não envolvem os úmeros e atingem o terço apical; extremidades elitrais arredondadas; lados do metasterno e fêmures sem pontos contrastantes e no abdômen pouco evidente. Brasil (Espírito Santo a Santa Catarina), Argentina (Misiones) .................. socium Martins \& Galileo, 1990

3. Pubescência elitral uniforme em toda a extensão, não entremeada por áreas glabras; fềmures vermelho-alaranjados com ápices pretos. Brasil (Rondônia a São Paulo, Minas Gerais, Espírito Santo)

rufipes Martins \& Galileo, 1990

- Pubescência elitral entremeada por pontos glabros ............... 4

4. Centro do pronoto com faixa longitudinal de pubescência branca; extremidades elitrais obliquamente truncadas, projetadas num espinho no lado externo. Peru. ......................................

- Pronoto sem faixa central de pubescência densa; extremidades elitrais subarredondadas. Colômbia, Venezuela ...... . elongata Galileo \& Martins, 1992 


\section{Lustrocomus, gen.n.}

\section{Espécie-tipo, Lustrocomus paraensis sp.n.}

Aspecto geral "lampiróide". Fronte mais larga do que longa, levemente abaulada. Granulação ocular moderada. Lobos oculares superiores tão distantes entre si quanto a aproximadamente o dobro da largura de um lobo; lobos oculares inferiores pouco mais longo do que as genas. Antenas com pêlos muito esparsos no lado interno. Escapo sem cicatriz apical. Flagelômeros lineares, não espessados. Antenômero III esbelto, tão longo quanto o IV. Protórax mais largo que longo com espinho lateral ao nível do terço basal com ápice levemente para atrás. Pronoto sem tubérculos. Mesosterno sem tubérculo. Élitros com pubescência e cerdas curtas; regularmente convexos sem depressão longitudinal ao lado da sutura; sem carenas longitudinais; declividade lateral com faixa longitudinal de pêlos brancos curtos. extremidades arredondadas. Sulco das mesotíbias central, pouco profundo. Metafêmures atingem a borda apical do urosternito II. Metatarsômero I tão longo quanto II + III. Dente interno das garras tarsais desenvolvido.

Discussão. Na chave para gêneros de Calliini (GALILEO \& MARTINS 1991), Lustrocomus insere-se no dilema 30, junto com Anapsicomus Galileo \& Martins, 1988 pelo aspecto geral "lampiroide", pela região centro-basal dos élitros não deprimida, com pontos simples; pelo escapo sem cicatriz; pelo mesosterno sem tubérculo e pela presença de espinho nos lados do protórax. Distingue-se de Anapsicomus pelos flagelômeros não intumescidos e alongados; pelo espinho lateral do protórax desenvolvido, curvo para trás e situado ao nível do terço posterior.

\section{Lustrocomus paraensis sp.n.}

Fig. 9

Macho. Cabeça com tegumento alaranjado com manchas de tegumento preto atrás dos olhos. Pubescência amarelo-dourada, exceto sobre a área de tegumento preto. Lobos oulares superiores com oito fileiras de omatídios. A extremidade do antenômero IX quase atinge o ápice elitral (antenômeros X e XI faltam). Escapo alaranjado com quarto apical preto; pedicelo e antenômeros III-VI pretos com anel basal de tegumento amarelado; antenômeros VII-IX pretos. Protórax alaranjado, grande área no dorso do pronoto acastanhada; pubescência branco-amarelada esparsa, mais concentrada nos lados do pronoto e do protórax. Pronoto com pontos profundos e esparsos. Élitros castanho-escuros a pretos; friso sutural e área longitudinal sobre a curvatura da declividade lateral, do úmero ao terço apical, com tegumento alaranjado; pubescência esbranquiçada, pouco mais longa sobre a faixa lateral alaranjada. Lados do mesosterno, mesepisternos, mesepimeros, metepisternos, maior parte do metasterno com tegumento acastanhado. Pro- e mesofêmures com tegumento alaranjado. Metafêmures alaranjados com área de tegumento escuro no terço apical. Tíbias alaranjadas na base e escurecidas para o ápice. Urosternitos com tegumento acastanhado e, nos lados, avermelhados. Face ventral sem pontuação; recoberta por pubescência esbranquiçada esparsa. Último urosternito com a borda apical subtruncada. 
Fêmea. Tegumento amarelado nas áreas correspondentes ao tegumento alaranjado nos machos. Último urosternito levemente intumescido indistintamente sulcado no meio da base. Ápice do antenômero VI atinge o meio dos élitros (antenômeros VII-XI faltam).

Dimensões macho/fêmea respectivamente. Comprimento total 5,7/6,3. Protórax: comprimento $1,0 / 1,1$; maior largura 1,6/1,8. Élitro: comprimento 4,2/4,8; largura umeral $1,8 / 2,1$.

Holótipo macho. Brasil, Pará: São Caetano, 19.III.1970, J.M. \& B.A. Campbell leg. (CNCI). Parátipo fềmea, mesmos dados do holótipo (MZSP).

Agradecimentos. A Flavio A. Bockmamn por nos haver alertado sobre a homonimia de Moema. A Antonio Claúdio Ferreira da Costa e Keti Zanol (Universidade Federal do Paraná) pelas informações sobre Taperinha Linnavuori. Aos curadores que enviaram material: R.A. Anderson (CMNC), J. MacNamara (CMCI), F. Fernandez (MHNB), M.A. Monné (MNRJ), R. Velez (UNCN).

\section{REFERÊNCIAS BIBLIOGRÁFICAS}

Bates, H.W. 1879-1885. Biologia Centrali-Americana, Coleoptera v. 5. Londres, British Museum of Natural History, 436p.

BUQUET, L. 1840a. Description de quelques coléoptères appartenant aux genres Calocomus, Stenaspis et Galissus. Revue Zool., Paris, p.142.

1840b. G. Calocome. Calocomus Serville. Mag. Zool., Paris, p.1-3.

CostA, W.J.E. M. 1989. Descrição e relações fillogenéticas de dois gêneros novos e três espécies novas de peixes anuais neotropicais (Cyprinodontiformes, Rivulidae). Rev. Bras. Biol., Rio de Janeiro, 49 (1): 221-230.

Dillon, L.S. \& E.S. Dillon. 1941. The tribe Monochamini in the Western Hemisphere (Coleoptera, Cerambycidae). Scient. Publs Reading Publ. Mus., Reading, 1: 1-135.

1945-46. The tribe Onciderini (Coleoptera, Cerambycidae). Scient. Publs Reading Publ. Mus., Reading, 5-6: 1-413.

GALILEO, M.H. M. \& U.R. MARTINS. 1991. Revisão da tribo Calliini (Coleoptera, Cerambycidae, Lamiinae). Giorn. ital. Ent., Cremona, 5: 243-262.

. 1992. Cerambycidae (Coleoptera) of the Canadian Museum of Nature, Ottawa. II. Calliini (Lamiinae). Insecta Mundi, Gainesville, 6: 135-139.

1994. Revisão da tribo Calocomini (Coleoptera, Cerambycidae, Prioninae). Revta bras. Ent., São Paulo, 38: 489-505.

LANE, F. 1964. Novos gêneros e espécies de Anisocerini (Coleoptera, Lamiidae). Stud. Ent., Petrópolis, 7: 179-200.

LinNAVUORI, R. 1959. Revision of the Neotropical Deltocephalinae and some related subfamilies (Homoptera). Ann. Zool. Soc. "Vanamo", Helsinky, 20 (1): $1-370$.

Martins, U. R. \& M.H.M. GaliLEO. 1989. Sobre Falsamblesthiini (Coleoptera, Cerambycidae, Lamiinae). III. Subsídios para uma revisão. Revta bras. Ent., 
São Paulo, 33: 119-134. 1990. Notas sobre Calliini (Coleoptera, Cerambycidae, Lamiinae). II. Descrição de três gêneros novos. Revta bras. Ent., São Paulo, 34: 475-480. 1992. O gênero Hilaroleopsis Lane, 1970 e descrições de novos táxons em Hemilophini (Coleoptera, Cerambycidae, Lamiinae). Revta bras. Ent., São Paulo, 36: 589-596.

Monné, M.A. 1980. Contribuição ao conhecimento dos Compsosomatini (Coleoptera, Cerambycidae, Lamiinae). Parte II. Revta bras. Ent., São Paulo, 24: $85-104$.

1994. Catalogue of the Cerambycidae (Coleoptera) of the Western Hemisphere. Part XVII, São Paulo, Sociedade Brasileira de Entomologia, 110p. Monné, M.A. \& E.F. GiesberT. 1993. Checklist of the Cerambycidae and Disteniidae (Coleoptera) of the Western Hemiphere. Burbank, Wolfsgarden, $\mathrm{XIII}+409 \mathrm{p}$.

NAPP, D.S. \& U.R. MARTINS. 1982. Subsídios para revisão taxonômica da tribo Achrysonini (Coleoptera, Cerambycidae) nas Américas. Papéis Avuls. Zool., São Paulo, 34: 349-401.

WHITE, A. 1853-1855. Catalogue of the coleopterous insects in the collection of the British Museum. Longicornia 1-2, Londres, British Museum, v. 7-8, 412p. 